УДК 342.922(477)

DOI https://doi.org/10.32844/2618-1258.2019.3-1.26

КІЗЬ C.M.

\title{
ПРИНЦИПИ ДІЯЛЬНОСТІ СПЕЦІАЛІЗОВАНОЇ АНТИКОРУПЦЙНОЇ ПРОКУРАТУРИ ЯК СУБ'СКТА РЕАЛІЗАЦІЇ ДЕРЖАВНОЇ АНТИКОРУПЦІЙНОЇ ПОЛІТИКИ В УКРАЇНІ
}

У статті проаналізовано наукові позиції вчених щодо розуміння принципів діяльності органів прокуратури, у тому числі й Спеціалізованої антикорупційної прокуратури. Надано власне розуміння діяльності Спеціалізованої антикорупційної прокуратури як суб'єкта реалізації державної антикорупційної політики. Сформовано авторський підхід до класифікації принципів діяльності Спеціалізованої антикорупційної прокуратури як суб'єкта реалізації державної антикорупційної політики. Визначено, що принципи діяльності Спеціалізованої антикорупційної прокуратури відіграють важливу роль у нормативно-правовому регулюванні діяльності даного органу кримінальної юстиції, виступають фундаментальною основою виконання покладених на нього повноважень та відображають спрямованість на утвердження верховенства права.

Наголошено, що успішна протидія корупції можлива за умови наявності таких складових: належного антикорупційного законодавства, ефективного його застосування відповідними органами державної влади і органами місцевого самоврядування, координації їх діяльності; ефективної системи протидії корупції в усіх сферах діяльності органів державної влади і органів місцевого самоврядування та на всіх рівнях; відкритості та інформованості громадськості про здійснення заходів щодо запобігання і протидії корупції; взаємодії об'єднань громадян з органами державної влади і органами місцевого самоврядування у сфері формування та реалізації державної антикорупційної політики, підтримки антикорупційних заходів держави громадянським суспільством.

Зроблено висновок, що принципи діяльність Спеціалізованої антикорупційної прокуратури як суб'єкта реалізації державної антикорупційної політики становлять собою керівні ідеї, які визначають основу для формування й реалізації завдань і функцій у роботі цих органів. В цілому принципи діяльності Спеціалізованої антикорупційної прокуратури як суб'єкта реалізації державної антикорупційної політики умовно слід класифікувати в наступні групи: 1) загальні; 2) особливі; 3) спеціальні (спрямовані на реалізацію державної антикорупційної політики).

Ключові слова: прокуратура, Спеціалізована антикорупџійна прокуратура, приниипи діяльності, державна антикорупиійна політика, корупиія, протидія, запобігання.

The article analyzes scientific positions of scientists concerning the understanding of the principles of the work of the prosecutor's office, including the Specialized AntiCorruption Prosecutor's Office. Self-actualization of the activities of the Specialized Anti-Corruption Prosecutor's Office as the subject of the implementation of the state anti-corruption policy is provided. An author's approach to the classification of the principles of the activity of the Specialized Anti-Corruption Prosecutor as the subject of the implementation of the state anti-corruption policy was formed. It is determined that the principles of activity of the Specialized Anti-Corruption Prosecutor's Office play an important role in the legal regulation of the activity of a given criminal justice body, serve as a fundamental basis for the implementation of the powers vested in it and reflect the focus on strengthening the rule of law.

It is emphasized that successful counteraction to corruption is possible provided that the following components are available: proper anti-corruption legislation, effective

(C) КІЗЬ С.М. - здобувач (Харківський національний університет внутрішніх справ) 
implementation of it by the relevant state and local self-government bodies, coordination of their activities; an effective system for combating corruption in all spheres of activity of state and local self-government bodies and at all levels; openness and public awareness of measures to prevent and counteract corruption; interaction of associations of citizens with public authorities and local self-government bodies in the formulation and implementation of state anti-corruption policy, support of anti-corruption measures of the state by civil society.

It is concluded that the principles of activity of the Specialized Anti-Corruption Prosecutor's Office as a subject of the implementation of the state anti-corruption policy are guiding ideas that determine the basis for the formation and realization of tasks and functions in the work of these bodies. In general, the principles of activity of the Specialized Anti-Corruption Prosecutor's Office as a subject of implementation of state anti-corruption policy should be conditionally classified into the following groups: 1) general; 2) special; 3) special (aimed at the implementation of state anti-corruption policy).

Key words: prosecutor's office, specialized anti-corruption prosecutor's office, principles of activity, state anti-corruption policy, corruption, counteraction, prevention.

Постановка проблеми. В умовах сьогодення корупція гальмує еволюцію правової системи, унеможливлюючи наближення України до передових світових показників рівня життя. Відсутність дієвих важелів боротьби з корупцією, поширення корупціогенних ризиків практично на всі сфери суспільного життя, лояльне ставлення частини громадян до вказаного явища призвели до того, що корупційна діяльність на всіх щаблях влади паралізувала проведення реформ, визначених керівництвом держави як пріоритет розвитку. Дієва протидія корупції неможлива без послідовних, спланованих і скоординованих дій, об'єднаних однією концепцією, оскільки системні явища потребують системного підходу в їх подоланні. Тому стратегічною метою антикорупційної політики, як в європейських країнах, так і в нашій державі є протидія корупції на всіх рівнях шляхом підвищення прозорості діяльності державних органів, додержання прав і свобод людини й громадянина, створення умов для розвитку економіки, забезпечення соціальних стандартів $\mathrm{i}$ добробуту населення [1, с. 11]. Недаремно в Стратегії сталого розвитку «Україна - 2020» наголошується на тому, що основною метою антикорупційної реформи є суттєве зменшення корупції в Україні, зменшення втрат державного бюджету та бізнесу через корупційну діяльність, а також підвищення позицій України у міжнародних рейтингах, що оцінюють рівень корупції [2].

Поряд із зазначеним, особливе місце у запобіганні та протидії корупційним проявам відводиться Спеціалізованій антикорупційній прокуратурі, яка повинна сприяти підвищенню ефективності виконання завдань щодо встановлення, розкриття найбільш небезпечних форм корупційних злочинів, викриття винних та забезпечення відшкодування збитків громадянам, суспільству та державі, а також удосконалення механізму визначення кримінальної та цивільної відповідальності за деякі злочини та інші правопорушення у сфері службової діяльності у напрямку підвищення відповідності вимогам демократичного суспільства та євроінтеграції [3].

Аналіз останніх досліджень і публікацій. Питанням діяльності органів прокуратури тією чи іншою мірою входять до предмета наукових інтересів таких сучасних учених: О.В. Анпілогова, В.В. Богуцького, М.Н. Берідзе, Ю.М. Грошевого, В.В. Долежана, М.В. Косюти, М.І. Малюги, І.С. Марочкіна, Т.Є. Мироненко, В.Т. Нор, С.М. Поповича, М.В. Руденка, В.П. Рябцева, М.К. Якимчука. Однак у роботах названих авторів проблематика діяльності спеціалізованої антикорупційної прокуратури не знайшла свого висвітлення. Серед наукових праць, в яких досліджуються адміністративно-правові засади діяльності спеціалізованої антикорупційної прокуратури, варто вказати праці учених В.О. Бєліка, Є.В. Вандіна, Д.М. Демківа, І.С. Ковальчука, І.О. Клочка, Н.М. Курко, А.В. Лапкіна, О.С. Проневича, К.О. Розсохи, Т.П. Яцика.

Виклад основного матеріалу. Формулювання сучасних принципів діяльності Спеціалізованої антикорупційної прокуратури становить собою одну з ключових проблем в реалізації антикорупційної політики в Україні. Вважається, що шляхом вирішення проблеми принципів можна забезпечити раціональність, дієвість та ефективність державного управління [4, с. 50; 5 , с. 184]. Недаремно в науковій літературі звертається увага, що в Україні тривалий час успішно функціонує олігархічна антикорупційна модель. Корупція дає змогу посадовим особам використовувати механізм як інструмент для досягнення приватних інтересів та сприяє відокремленню державного апарату від суспільства. Корумповані бюрократичні структури існують в умовах непрозорості, 
нечіткої визначеності відповідальності та звітності, що дає можливість корупціонерам швидко пристосовуватися до будь-яких спалахів кампаній боротьби з корупцією за допомогою вибіркових заходів законодавчого та інституційного реформування [6, с. 109]. В той же час, в правничій літературі існують різні наукові позиції щодо розуміння принципів та їх класифікації. Це, у свою чергу, є свідченням багатогранності та багатоаспектності призначенням принципів у тій або іншій сфері людської діяльності.

У правовій доктрині, визначаючи поняття принципів права, науковці вживають такі категорії, як: вихідні теоретичні положення, основні, керівні засади (ідеї), загальні нормативно-керівні положення, провідні засади, закономірність, сутність, система координат тощо [7, с. 40]. Так, А.М. Колодій принципи права визначає як відправні ідеї його буття, які виражають найважливіші закономірності і підвалини даного типу держави і права, є однопорядковими із сутністю права і утворюють його основні риси, відрізняються універсальністю, вищою імперативністю і загальнозначимістю, відповідають об' єктивній необхідності побудови і зміцнення певного суспільного ладу $[8$, с. 117$]$.

В той же час, О.В. Старчук наголошує на тому, що практично всі науковці сходяться на тому, що принципи права - це такі засадничі ідеї права, які визначають зміст і спрямованість його норм та характеризуються системністю, взаємоузгодженістю, загальнообов'язковістю, універсальністю, стабільністю, предметною визначеністю, загальнозначущістю й регулятивністю [7, с. 42].

Аналізуючи праці Г.В Атаманчука, слід дійти висновку, що вчений пропонує певний варіант системи принципів, який має наступний вигляд: 1) загальносистемні принципи державного управління (об'єктивність, демократизм, правова впорядкованість, законність, федералізм, розподіл влади, публічність); 2) структурні (структурно-цільові; структурно-функціональні; структурно-організаційні та структурно-процесуальні); 3) спеціалізовані (принципи державної служби, технологізації державного управління, адміністративного процесу тощо) [9, с. 269-278].

Поділ принципів державного управління на загальносистемні, структурні та спеціалізовані має свою підтримку в багатьох працях вчених. Крім того, Г.В. Атаманчук звертає увагу на те, що принципи управління мають відповідати певним вимогам: 1) відображати тільки найбільш суттєві, головні закономірності та взаємозв'язки в державному управлінні; 2) характеризувати лише стійкі закономірності, відносини та взаємозв'язки; 3) охоплювати переважно такі закономірності, відносини, взаємозв'язки, які властиві державному управлінню як цілісному соціальному явищу; 4) відображати специфіку державного управління, його відмінність від інших видів управління [9, с. 265].

У свою чергу, Н. Нижник та О. Машков формулюють одночасно декілька визначень даного поняття: це і «основні правила», i «керівні ідеї», і «об'єктивні закономірності», що визначають зміст, організаційну структуру та життєдіяльність компонентів державного управління [4, с. 50-51].

Поряд із вказаним, варто вести мову про те, що сама по собі ідея, яка б вона видатна не була, поза правом не може мати імперативного зобов'язального характеру з відповідними санкціями. Тому ідеї юридичного значення і повинні мати правову форму. Але не кожна правова норма $\epsilon$ принципом, а лише та, яка $\epsilon$ найбільш узагальнююча, в плані регулювання складних суспільних відносин. Образно можна сказати, що принципи виступають немовби «згустками законів» $[10$, с. 69]. У цьому випадку принципи діяльності Спеціалізованої антикорупційної прокуратури - це безумовні вимоги, які закріплені у нормативно-правових актах або слідують безпосередньо зі змісту відповідних правових норм та є обов'язковими для виконання.

У свою чергу, В.I. Малюга на підставі аналізу думок різних авторів щодо визначення принципів організації та діяльності прокуратури, дійшов висновку, що принципи - це закріплені у законодавстві України, основні начала, положення, що обумовлені природою держави, рівнем розвитку суспільства, які визначають суть, зміст організації та функціонування прокуратури, характер повноважень прокурора і правові засоби їх здійснення [10, с. 71]. Ці принципи відображають погляди суспільства на те, як повинна бути організована прокуратура, якими методами i засобами повинен здійснюватися нагляд, які завдання виконувати. Значення принципів полягає в тому, що вони є основою для формування здатності і уміння дотримуватись працівником прокуратури постійної лінії поведінки, зразково виконувати свої обов'язки, вони є важливим засобом досягнення поставленої мети, виконання завдань і функцій, що покладаються на прокуратуpy $[10$, c. 72$]$.

В той же час М.I. Мичко вказує, що принципи організації і діяльності прокуратури - це закріплені в Конституції та інших законах основоположні вимоги, які виражають соціальне і державне призначення прокуратури, визначають завдання і повноваження прокурорів, а також зміст 
і характер правових засобів і методів діяльності прокурорів по здійсненню покладених на них функцій, а також містять у собі ознаки якості, що визначають організаційний устрій прокуратури, відмінність іï від інших державних органів, в тому числі і від правоохоронних [11, с. 295].

Безпосереднє звернення до Закону України «Про прокуратуру» надає можливість вказати основні принципи організації та діяльності органів прокуратури, які безпосередньо стосуються й діяльності Спеціалізованої антикорупційної прокуратури, оскільки остання становить єдину систему прокуратури України, а саме: 1) верховенства права та визнання людини, іiі життя і здоров'я, честі і гідності, недоторканності і безпеки найвищою соціальною цінністю; 2) законності, справедливості, неупередженості та об'єктивності; 3) територіальності; 4) презумпції невинуватості; 5) незалежності прокурорів, що передбачає існування гарантій від незаконного політичного, матеріального чи іншого впливу на прокурора щодо прийняття ним рішень при виконанні службових обов'язків; 6) політичної нейтральності прокуратури; 7) недопустимості незаконного втручання прокуратури в діяльність органів законодавчої, виконавчої і судової влади; 8) поваги до незалежності суддів, що передбачає заборону публічного висловлювання сумнівів щодо правосудності судових рішень поза межами процедури їх оскарження у порядку, передбаченому процесуальним законом; 9) прозорості діяльності прокуратури, що забезпечується відкритим і конкурсним зайняттям посади прокурора, вільним доступом до інформації довідкового характеру, наданням на запити інформації, якщо законом не встановлено обмежень щодо ії надання; 10) неухильного дотримання вимог професійної етики та поведінки [12].

У контексті вказаного, К.О. Розсоха принципи діяльності Спеціалізованої антикорупційної прокуратури поділяє за двома критеріями: за джерелом закріплення та за напрямом правового регулювання [13, с. 77]. У свою чергу, до принципів діяльності Спеціалізованої антикорупційної прокуратури за джерелом закріплення належать: 1) конституційні - принцип верховенства права; 2) галузеві - принципи, передбачені Законом України «Про прокуратуру» - незалежність Спеціалізованої антикорупційної прокуратури від інших владних органів; єдність та централізація органів прокуратури; 3) міжгалузеві - гласність, публічність, заборона сумісництва тощо. За напрямом правового регулювання принципи Спеціалізованої антикорупційної прокуратури можна розділити на організаційні, функціональні та змішані [13, с. 77].

Слушною є наукова праця Ю.О. Коваленка, який досліджує принципи інформаційного забезпечення протидії корупції в правоохоронних органах України, які становлять собою цілісну систему об'єктивно зумовлених засадничих загальноправових, адміністративно-правових та специфічних для процесу інформаційного забезпечення ідей, котрі є основою для діяльності суб'єктів інформаційної сфери щодо належного та оптимального здійснення інформаційного забезпечення протидії корупції в правоохоронних органах України таким чином, щоби досягти мети цього інформаційного забезпечення та сприяти забезпеченню прав і свободи людини та громадянина, нормальному функціонуванню громадянського суспільства, а також держави у цілому [14, с. 57].

Вчений виокремлює відповідну систему принципів інформаційного забезпечення протидії корупції в правоохоронних органах України, та складають: (1) загальноправові принципи (принципи справедливості, гуманізму, законності, демократизму, верховенства права, юридичної рівності усіх перед законом, взаємної відповідальності держави та особи, гласності та прозорості застосування юридичних норм); (2) міжгалузеві принципи, котрі є результатом поєднання відповідних блоків адміністративно-правових та інформаційно-правових галузевих принципів (зокрема, це принципи: субординації, визначення мінімально необхідних повноважень органів державної виконавчої влади, об'єктивності, достовірності, повноти та своєчасності інформації тощо); (3) спеціальні принципи (принципи актуальності та достовірності, об'єктивності та повноти, системності та цілеспрямованості, активності та ініціативності) [14, с. 57].

Серед наукових праць, в яких досліджувались питання діяльності Спеціалізованої антикорупційної прокуратури варто вказати працю Д.М. Демківа, який наголошує на тому, що принципи діяльності Спеціалізованої антикорупційної прокуратури відіграють важливу роль у нормативно-правовому регулюванні діяльності даного органу кримінальної юстиції, виступають фундаментальною основою виконання покладених на нього повноважень та відображають спрямованість на утвердження верховенства права [15, с. 146].

Н.М. Курко під принципами антикорупційної діяльності прокуратури розуміє нормативно закріплені ідеї, вимоги та положення, що покладаються в основу їх формування та реалізації [16, с. 68]. В межах свого дисертаційного дослідження Н.М. Курко наголошує на тому, що антикорупційна діяльність прокуратури має базуватися на принципах закріплених в конституції України та інших законах, а саме: верховенства права; законності; компетентності; незалежності; 
пріоритетності запобіжних заходів; невідворотності відповідальності за вчинення корупційних або пов'язаних з корупцією правопорушень; прозорості та доступу до інформації; участі громадськості у заходах щодо запобігання корупції; забезпечення відновлення порушених прав i законних інтересів та відшкодування збитків, шкоди, завданої корупційним правопорушеннями; етичної поведінки [16, с. 68-69]. В цілому погоджуючись із запропонованою системою принципів антикорупційної діяльності прокуратури, але в той же час, вони становлять відповідну систему принципів організації і діяльності прокуратури антикорупційного спрямування.

Зрозуміло, що будь-який класифікаційний розподіл має досить суб'єктивний характер, оскільки кожен з авторів намагається запропонувати і обгрунтувати власний погляд на класифікацію залежно від суб'єктивного розуміння того чи іншого явища. Разом із тим, множинність існуючих класифікацій дозволяє розглянути досліджуване явище з різних боків і більш ретельніше. Наведений аналіз широкого спектру думок свідчить про те, що принципи права $є$ базовою категорією, вихідним началом, керівною ідеєю формування та функціонування держави, побудови її внутрішніх і зовнішніх зв'язків, де людина та іії права $є$ найвищою соціальною цінністю.

Враховуючи те, що в межах даної праці досліджуються питання принципів діяльності Спеціалізованої антикорупційної прокуратури як суб'єкта реалізації державної антикорупційної політики, то під «антикорупційною політикою» слід розуміти комплексну нормативну діяльність спеціально уповноважених органів держави, громадськості, юридичних осіб та окремих громадян, яка пов'язана 3 іншими видами державної політики, відповідає міжнародним принципам протидії корупції, має програмний характер, спрямована на формування та реалізацію норм антикорупційного законодавства і вирішує завдання системної протидії корупції [17, с. 7].

Дійсно успішна протидія корупції можлива за умови наявності таких складових: належного антикорупційного законодавства, ефективного його застосування відповідними органами державної влади і органами місцевого самоврядування, координації їх діяльності; ефективної системи протидії корупції в усіх сферах діяльності органів державної влади і органів місцевого самоврядування та на всіх рівнях; відкритості та інформованості громадськості про здійснення заходів щодо запобігання і протидії корупції; взаємодії об'єднань громадян з органами державної влади і органами місцевого самоврядування у сфері формування та реалізації державної антикорупційної політики, підтримки антикорупційних заходів держави громадянським суспільством [18].

В той же час, аналіз норм діючого законодавства надає можливість виокремити принципи діяльності Спеціалізованої антикорупційної прокуратури як суб'єкта реалізації державної антикорупційної політики: 1) рівність усіх перед законом; 2) забезпечення дотримання прав і свобод людини і громадянина у відносинах з органами державної влади та органами місцевого самоврядування; 3) дотримання правових норм у сфері запобігання і протидії корупції; 4) невідворотність юридичної відповідальності за вчинення корупційного правопорушення; 5) надання пріоритету превентивним антикорупційним заходам; 6) відкритість і прозорість діяльності Спеціалізованої антикорупційної прокуратури щодо реалізації державної антикорупційної політики; 7) поєднання зусиль держави і громадськості у подоланні корупції як системного явища в усіх сферах суспільного життя [18].

Висновки. Таким чином, принципи діяльність Спеціалізованої антикорупційної прокуратури як суб'єкта реалізації державної антикорупційної політики становлять собою керівні ідеї, які визначають основу для формування й реалізації завдань і функцій у роботі цих органів. В цілому принципи діяльності Спеціалізованої антикорупційної прокуратури як суб'єкта реалізації державної антикорупційної політики умовно слід класифікувати в наступні групи: 1) загальні; 2) особливі; 3) спеціальні (спрямовані на реалізацію державної антикорупційної політики). В перспективному напрямку, робота буде спрямовано на розкриття змісту виокремленних принципів діяльність Спеціалізованої антикорупційної прокуратури.

\section{Список використаних джерел:}

1. Клімова С.М., Ковальова Т.В. Організаційно-правове забезпечення сучасної антикорупційної політики : навч. посіб. Харків, 2015. 252 с.

2. Про Стратегію сталого розвитку «Україна - 2020»: Указ Президента України від 12.01.2015 № 5/2015 URL : https://zakon.rada.gov.ua/go/5/2015.

3. Про внесення змін до деяких законодавчих актів України щодо діяльності Національного антикорупційного бюро України : Пояснювальна записка до проекту Закону України Закону України від 27.12.2014 № 1660 URL: http://w1.c1.rada.gov.ua/pls/zweb2/ webproc34? id=\&pf3511=53224\&pf 35401=322695. 
4. Нижник Н.Р., Машков О. А. Системний підхід в організації державного управління. Київ : УАДУ, 1998. 160 с.

5. Кунєв Ю. А. Сучасна модель системи принципів державного управління. Вісник ЗЮІ МВС Украӥни. 2001. № 4. С.184-193.

6. Береза О.Д. Державна антикорупційна політика: сутність та особливості реалізації в постіндустріальному суспільстві: дис. ... канд. юрид. наук : 25.00.01. Київ, 2016. 218 с.

7. Старчук О.В. Щодо поняття принципів права. Часопис Київського університету права. 2012. № 2. С.40-43.

8. Колодій А.М. Конституція і розвиток принципів права (методологічні питання): дис. ... д-ра юрид. наук : 12.00.01; 12.00.02. Київ, 1998. 391 с. $584 \mathrm{c}$.

9. Атаманчук Г.В. Теория государственного управления : курс лекцій. М. : Омега-Л, 2004.

10. Малюга В.І. Принципи організації та діяльності прокуратури України : дис. канд. юрид. наук: 12.00.10. Київ, 2002. 205 с.

11. Мичко М.І. Проблеми функцій і організаційного устрою прокуратури України : дис. ... канд. юрид. наук: 12.00.10. Харків, 2002. 376 с.

12. Про прокуратуру : Закон України від 14.10.2014 № 1697-VII URL: https://zakon.rada. gov.ua/go/1697-18.

13. Розсоха К.О. Прокуратура в системі спеціалізованих антикорупційних органів України : дис. ... канд. юрид. наук: 12.00.10. Харків, 2019. 204 с.

14. Коваленко Ю.О. Адміністративно-правовий механізм інформаційного забезпечення протидії корупції в правоохоронних органах України : дис. ... канд. юрид. наук: 12.00.07. Київ, 2018. 249 c.

15. Демків Д.М. Адміністративно-правове забезпечення взаємодії спеціалізованої антикорупційної прокуратури з іншими правоохоронними органами : дис. ... канд. юрид. наук: 12.00.07. Тернопіль, 2019. 256 с.

16. Курко Н.М. адміністративно-правове регулювання антикорупційної діяльності прокуратури України : дис. ... канд. юрид. наук: 12.00.07. Київ, 2015. 191 с.

17. Грабець І.Н. Адміністративно-правові засади діяльності прокурора щодо протидії адміністративним правопорушенням, пов'язаним з корупцією в Україні : автореф. дис. канд. юрид. наук: 12.00.07. Київ, 2015. 23 с.

18. Про Національну антикорупційну стратегію на 2011-2015 роки : Указ Президента України від 21.10.2011 № 1001/2011 URL: https://zakon.rada.gov.ua/go/1001/2011. 